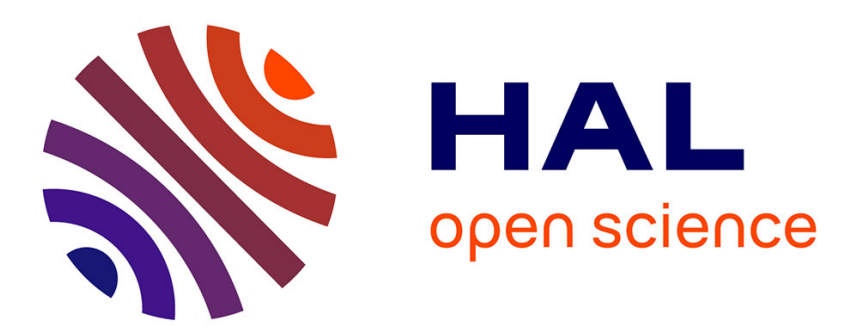

\title{
Difluorodeoxyuridine plasma concentrations after low-dose gemcitabine during chemoradiation in head and neck cancer patients
}

P. Specenier, G. Guetens, J. Dyck, G. Boeck, J. Weyler, D. Weyngaert, K. Aelbrecht, J. B. Vermorken

\section{To cite this version:}

P. Specenier, G. Guetens, J. Dyck, G. Boeck, J. Weyler, et al.. Difluorodeoxyuridine plasma concentrations after low-dose gemcitabine during chemoradiation in head and neck cancer patients. Cancer Chemotherapy and Pharmacology, 2010, 68 (1), pp.185-191. 10.1007/s00280-010-1471-1 . hal00627933

\section{HAL Id: hal-00627933 \\ https://hal.science/hal-00627933}

Submitted on 30 Sep 2011

HAL is a multi-disciplinary open access archive for the deposit and dissemination of scientific research documents, whether they are published or not. The documents may come from teaching and research institutions in France or abroad, or from public or private research centers.
L'archive ouverte pluridisciplinaire HAL, est destinée au dépôt et à la diffusion de documents scientifiques de niveau recherche, publiés ou non, émanant des établissements d'enseignement et de recherche français ou étrangers, des laboratoires publics ou privés. 


\section{Difluorodeoxyuridine plasma concentrations after low dose gemcitabine during chemoradiation in head and neck cancer patients}

Specenier $P^{1}$, Guetens $G^{2}$, Dyck $]^{1}$, De Boeck $G^{2}$, Weyler $J^{3}$, Van den Weyngaert $D^{4}$, Aelbrecht $\mathrm{K}^{1}$, Vermorken $\mathrm{JB}^{1}$

${ }^{1}$ Medical Oncology, Antwerp University Hospital, Edegem, Belgium

${ }^{2}$ Laboratory of Cancer Research and Clinical Oncology, Antwerp University, Wilrijk, Belgium

${ }^{3}$ Epidemiology and Community Medicine, Antwerp University, Wilrijk, Belgium

${ }^{4}$ Radiotherapy, Antwerp University Hospital, Edegem, Belgium

Correspondance:

Pol Specenier

Antwerp University Hospital

Wilrijkstraat 10

2650 Edegem

Belgium

Pol.specenier@uza.be

32 (3) 8214014 


\section{Abstract}

Purpose: The aim of this study was to investigate whether relevant plasma levels of dFdU could be detected during concurrent chemoradiation (CRT) with low doses of dFdC administered in patients with head and neck cancer and to assess the toxicity related to dose.

Methods: dFdC was administered at doses of $5 \mathrm{mg} / \mathrm{m}^{2}$ twice weekly or 10,50 or 100 $\mathrm{mg} / \mathrm{m}^{2}$ weekly. Plasma concentrations of $\mathrm{dFdU}$ were determined daily for 7 days after the first administration and before each administration, thereafter. A high-performance liquid chromatographic method was used. During CRT, skin and mucosal toxicity were scored weekly according to the RTOG toxicity scoring system.

Results: Eight patients were sampled at the 10 and $50 \mathrm{mg} / \mathrm{m}^{2}$ dose and nine at the 5 and $100 \mathrm{mg} / \mathrm{m}^{2}$ dose. dFdU levels were in the micromolar range, inducing $\mathrm{RS}$ in vitro.There was a strong correlation between the area under the curve of $\mathrm{dFdU}$ and the dose of dFdC $(r=0.803, p<0.001)$ and a weak correlation between trough concentrations and total dose of $\mathrm{dFdC}(r=0.408, p=0.017)$. Duration of severe mucositis correlated with $\mathrm{dFdC}$ dose.

Conclusions: During CRT with $10-100 \mathrm{mg} / \mathrm{m}^{2}$ of $\mathrm{dFdC}$ weekly or $5 \mathrm{mg} / \mathrm{m}^{2}$ twice weekly, $\mathrm{dFdU}$ remains detectable at potentially radiosensitizing concentrations. 


\section{Introduction}

Gemcitabine $\left(2^{\prime}, 2^{\prime}\right.$-difluorodeoxycytidine; $\left.d F d C\right)$ is a fluorinated pyrimidine nucleoside analogue (1) with antitumor activity against a wide variety of tumors, including head and neck cancer (2). Gemcitabine is a prodrug that requires several steps of phosphorylation to yield the active metabolites difluorodeoxycytidine diphosphate ( $\mathrm{dFdCDP}$ ) and difluorodeoxycytidine triphosphate (dFdCTP), which target DNA and RNA and are presumably responsible for the cytotoxic effect $(1,3,4)$. dFdCTP is incorporated into DNA and inhibits DNA polymerase processing, whereas dFdCDP interferes with the enzyme ribonucleotide reductase, causing depletion of deoxynucleotide triphosphate necessary for DNA synthesis. The rate limiting step is the phosphorylation of gemcitabine into difluorodeoxycytidine monophosphate by deoxycytidine kinase (5-7). In addition to its cytotoxic effects, gemcitabine has potent radiosensitizing properties, as shown both in preclinical and clinical settings, with in vitro radioenhancement factors up to three, depending upon schedule and concentration (8). The current evidence suggests that accumulation in the $S$ phase of the cell cycle, depletion of dATP pools, reduction of apoptotic threshold, inhibition of DNA synthesis and reduction of DNA repair might contribute to, or might even be essential for gemcitabine-mediated radiosensitization (913).

The radiosensitizing properties of gemcitabine have been exploited in patients with pancreatic cancer $(8,14,15)$, other gastrointestinal cancers (8), lung cancer (8), cancer of the uterine cervix $(16,17)$ and head and neck cancer (18-20). In patients, gemcitabine is rapidly cleared from the plasma with a half-life of only a few minutes (21, 22). It is deaminated by deoxycytidine deaminase to its main metabolite difluorodeoxyuridine ( $\mathrm{dFdU}$ ) which has little cytotoxic activity at clinically relevant levels (23). However, dFdU has clear radiosensitizing properties in vitro when given in micromolar ranges (23) and has the additional advantage of a prolonged half-life (21, 22). Our hypothesis was that the radiosensitizing potential of dFdU could be of clinical importance even when very low doses of gemcitabine are given, when this metabolite would be continuously available in plasma in concentrations that in vitro are inducing 
radiosensensitization. We therefore measured dFdU concentrations in plasma in patients with tumors in the head and neck region who were treated with low dose gemcitabine during chemoradiation.

\section{Patients and methods}

\section{Study objectives}

The aims of this study were to investigate whether relevant plasma levels of dFdU could be detected during concurrent chemoradiation with low doses of gemcitabine administered in patients with cancer in the head and neck region and to assess the acute toxicity related to gemcitabine dose.

\section{Eligibility criteria}

Included were patients who were considered fit enough by the multidisciplinary team of dedicated head and neck surgeons, radiotherapists and medical oncologists to receive gemcitabine-based concurrent chemoradiaton for tumors located in the head and neck region, with no restrictions regarding the site of the tumor, the histology, the disease setting (either after induction chemotherapy or as definitive chemoradiation or adjuvantly

after surgery), age, performance status, or organ functions (serum creatinine, liver enzymes). Patients were informed about the pros and cons of gemcitabine-based chemoradiation and were to give informed consent.

\section{Treatment}

Concurrent chemoradiation was given either as definitive treatment alone or after induction chemotherapy or in the postoperative setting. The planned irradiation dose was 66-70 Gy in 33-35 fractions of 2 Gy over 6.5-7 weeks. Gemcitabine was administered over 30 minutes within 2 hours before irradiation at doses of $5 \mathrm{mg} / \mathrm{m}^{2}$ twice weekly or 10,50 or $100 \mathrm{mg} / \mathrm{m}^{2}$ weekly along with radiation therapy.

\section{Blood sampling and storage}

Ten milliliter blood was drawn into a lithium heparin tube every 24 hours for 7 days, starting 24 hours after the first administration of gemcitabine, and before each 
administration thereafter. Hundred microliter of a tetrahydrouridine (THU) solution $10 \%$ was added. The mixture was vortexed immediately at 3941 rounds per minute for 15 minutes and the plasma was stored at minus $20^{\circ} \mathrm{C}$.

\section{Analysis of dFdU in plasma}

A high-performance liquid chromatographic (HPLC) method was used and validated for the determination of dFdU in human plasma. Floxuridine (5-flouro-2'-deoxyuridine was used as an internal standard. Tetrahydrouridine (THU) was used to prevent the deamination of gemcitabine to dFdU after sampling. Standard samples of blanc plasma were spiked with $\mathrm{dFdU}$ (50 $\mathrm{ng}-50.000 \mathrm{ng}$ ) and extracted in the same way as the other samples and used for a calibration curve. Separation was achieved isocratic on a Chrompack Sperisorb ODS-2 column (5 $\mu \mathrm{m}, 4,6 \times 250 \mathrm{~mm}$ ). The mobile phase was Pic B7 (Water Corporation) in a $10 \%$ methanol solution $(\mathrm{pH} 3,1)$ with a flow rate of 1,0 $\mathrm{ml} / \mathrm{min}$. The analytes were detected by ultra violet detection at $270 \mathrm{~nm}$. The limit of detection was about $50 \mathrm{ng} / \mathrm{ml}$ for dFdU. Within-run and between-run precisions were less than $10 \%$ and average accuracies were between 90 and $110 \%$.

\section{Plasma Extraction}

For the sample pretreatment procedure, $100 \mu \mathrm{l}$ internal standard work solution and $50 \mu \mathrm{l}$ of a THU solution $(10 \mathrm{mg} / \mathrm{ml}$ ) were added to $200 \mu \mathrm{l}$ of plasma. After vortexing, the sample was treated with $6 \mathrm{ml}$ of iso-propanol (15\%) in ethyl acetate and mixed thoroughly. After centrifugation, the organic phase was transferred to a glass tube and evaporated till dry by vacuum centrifugation. The residue was redissolved in $1 \mathrm{ml}$ of the mobile phase (a $5 \times$ dilution) and filtered over a $0.45 \mu \mathrm{m}$ PVDF HPLC-filter (Acrodisc, Waters Corporation) for HPLC injection $(20 \mu \mathrm{l})$.

\section{Calculations and toxicity scoring}

The dFdU area under the curve during the first week of treatment was calculated using the trapezoid method. The mean trough concentration of dFdU for each patient and the median of the mean trough concentrations for each dose level were calculated.

The acute mucosal and skin toxicity during the chemoradiation were scored weekly according to the RTOG Acute Radiation Morbidity Scoring Criteria (24) by the same very 
experienced radiotherapist who was blinded to the gemcitabine dose. The sum of the number of weeks with grade 3 or 4 toxicity during the treatment was calculated for each patient.

\section{Statistics}

Correlations were calculated using the Spearman's rho test. Means were compared using the one way ANOVA after performing a Levene's test in order to exclude significant variances within groups. All statistical analyses were calculated using Statistical Package for Social Sciences (SPSS) version 15.

\section{Results}

\section{Patient population}

Thirty-four patients were included in the study between October 2006 and June 2008.

Patient, tumor and treatment characteristics are summarized in table 1 . The results are summarized in tables 2 and 3 . Eight of the 34 patients received chemoradiation in the postoperative setting, five in the $5 \mathrm{mg} / \mathrm{m}^{2}$ dose group and one each in the other dose groups. Therefore, the patients in the $5 \mathrm{mg} / \mathrm{m}^{2}$ dose group received proportionally a lower radiation dose than the other three groups. The area under the concentration-time curve (AUC) of dFdU by dose level of dFdC during the first week of treatment is shown in figure 1. We found a clear correlation between the AUC of dFdU and the gemcitabine dose level (Spearman's rho $=0.805 ; \mathrm{p}<0.0001)$.

Figure 2 shows the dFdU concentrations versus gemcitabine dose for each day during the first week of treatment. Of notice, in the $5 \mathrm{mg} / \mathrm{m}^{2}$ dose group, patients received the second administration after the trough concentrations measured on day 4 . Figure 3 shows the means and the $95 \%$ confidence intervals of all dFdU trough concentrations by $\mathrm{dFdC}$ dose $\left(\mathrm{mg} / \mathrm{m}^{2}\right)$. Mean dFdU trough concentrations were not significantly different between the four different dose levels. Difluorodeoxyuridine remained detectable in plasma of the majority of patients even after doses as low as $10 \mathrm{mg} / \mathrm{m}^{2}$ once weekly or 5 
$\mathrm{mg} / \mathrm{m}^{2}$ twice weekly. However, there was a wide interpatient variation as illustrated by the wide confidence intervals.

Skin and mucosal toxicity is summarized in table 4 . The majority of patients developed grade 3 or 4 mucositis and grade 2 radiodermatitis, regardless of the dFdC dose. However, there was a correlation between the sum of the number of weeks with grade 3 or 4 mucositis during the treatment and the gemcitabine dose given during irradiation (figure 4; Spearman's rho: $0.592 ; \mathrm{p}<0.0001$ ). Hematologic toxicity is summarized in table 5 . Grade 3 or 4 hematological toxicity was rare and occurred only in patients who had received prior induction chemotherapy before the concurrent use of low-dose gemcitabine and radiation.

\section{Discussion}

Difluorodeoxyuridine remained detectable in plasma of our patients, even after administration of doses of gemcitabine as low as $10 \mathrm{mg} / \mathrm{m}^{2}$ once weekly or $5 \mathrm{mg} / \mathrm{m}^{2}$ twice weekly. There were substantial interpatient variations at the four studied dose levels, reflecting the wide variation in pharmacokinetics and pharmacodynamics of the drug (25-28). Indeed gene polymorphisms were reported for several enzymes involved in dFdC metabolism, including deoxycytidine kinase and cytidine deaminase (29-31). Difluorodeoxyuridine was previously shown to be a very potent radiosensitizer in vitro in multiple cell lines after exposure for only 24 hours, even at a concentration of $10 \mu \mathrm{M}$ (23). In most of our patients, we measured trough concentrations within the micromolar range. Moreover, if we take into account that the elimination of dFdU after the second and subsequent administrations follows the same pattern as after the first administration, considerably higher levels of dFdU were probably present for several days during the radiation in the majority of patients, even at these low gemcitabine dosages. Although multiple factors most likely are responsible for the radiosensitizing effect of dFdC (9-13), the sustained presence of dFdU in the blood could at least partly explain the often dramatic radioenchancement which is observed after administration of gemcitabine, despite short half life of the parent drug. 
We are fully aware of the limitations of this study due to the low number of patients in each treatment cohort and the differences in age, tumor type, tumor site, and tumor stage. However, with these limitations in mind, we observed no correlation between the dose or dose level and the maximum grade of skin and/or mucosal toxicity. In contrast, when we took into account the duration of grade 3 or 4 toxicity during the treatment, a significant correlation was observed between the weeks spent with grade 3 or 4 mucositis and dose level. The heterogeneity of the patient and treatment characteristics precludes any evaluation of the long term toxicity related to gemcitabine dose.

Concomitant chemoradiation with low doses of gemcitabine induces little hematologic toxicity, even after prior induction chemotherapy. Renal toxicity is extremely rare, even at standard cytotoxic doses (32). When used as a single agent, gemcitabine does not cause neurotoxicity or ototoxicity (32). These characteristics of the compound can be extremely useful in patients previously treated with cisplatin (e.g. after induction chemotherapy), or in patients with preexisting neurophathy, hearing loss or impaired renal function. Nevertheless, caution is warranted when patients are treated with severe impairment of the renal function, as elimination of $\mathrm{dFdU}$ is dependent on renal excretion and can accumulate in patients with renal failure $(33,34)$.

The parameters in this study, as summarized in table 2, are of course not sufficient to discuss the complete pharmacokinetic profile of gemcitabine and dFdU.

We conclude that during chemoradiation with $10-100 \mathrm{mg} / \mathrm{m}^{2}$ of gemcitabine weekly or 5 $\mathrm{mg} / \mathrm{m}^{2}$ twice weekly, dFdU remains detectable at potentially radiosensitizing concentrations. Such gemcitabine doses are significantly correlated with the AUC of dFdU and the duration of severe mucositis.

\section{References}

1. Heinemann V, Hertel LW, Grindey GB, Plunkett W (1988) Comparison of the cellular pharmacokinetics and toxicity of 2',2'-difluorodeoxycytidine and 1-beta-Darabinofuranosylcytosine. Cancer Res 48: 4024-4031 
2. Catimel G, Vermorken JB, Clavel M et al (1994) A phase II study of Gemcitabine (LY 188011) in patients with advanced squamous cell carcinoma of the head and neck. EORTC Early Clinical Trials Group. Ann Oncol 5: 543-547

3. Huang P, Chubb S, Hertel LW, Grindey GB, Plunkett W (1991) Action of 2',2'difluorodeoxycytidine on DNA synthesis. Cancer Res 51(22): 6110-6117

4. Ruiz van Haperen VW, Veerman G, Vermorken JB, Peters GJ (1993) 2',2'-Difluorodeoxycytidine (gemcitabine) incorporation into RNA and DNA of tumour cell lines. Biochem Pharmacol 46: 762-726

5. Bergman AM, Pinedo HM, Peters GJ (2002) Determinants of resistance to $2^{\prime}, 2^{\prime}$ difluorodeoxycytidine (gemcitabine). Drug Resist Updat 5: 19-33

6. van der Wilt CL, Kroep JR, Bergman AM, Loves WJ, Alvarez E, Talianidis I, Eriksson S, van Groeningen CJ, Pinedo HM, Peters GJ (2000) The role of deoxycytidine kinase in gemcitabine cytotoxicity. Adv Exp Med Biol 486: 287-290

7. Kroep JR, Loves WJ, van der Wilt CL, Alvarez E, Talianidis I, Boven E, Braakhuis BJ, van Groeningen CJ, Pinedo HM, Peters GJ. Pretreatment deoxycytidine kinase levels predict in vivo gemcitabine sensitivity. Mol Cancer Ther 2002; 1: 371-376

8. Pauwels B, Korst AEC, Lardon F, Vermorken JB (2005) Combined Modality Therapy of Gemcitabine and Radiation. Oncologist 10: 34-51 
9. Pauwels B, Vermorken JB, Wouters A, Ides J, Van Laere S, Lambrechts HA, Pattyn GG, Vermeulen K, Meijnders P, Lardon F (2009) The role of apoptotic cell death in the radiosensitising effect of gemcitabine. $\mathrm{Br}$ J Cancer 101: 628-636

10. Morgan MA, Parsels LA, Parsels JD, Mesiwala AK, Maybaum J, Lawrence TS (2005) Role of checkpoint kinase 1 in preventing premature mitosis in response to gemcitabine. Cancer Res 65: 6835-6842

11. Wachters FM, van Putten JW, Maring JG, Zdzienicka MZ, Groen HJ, Kampinga HH (2003) Selective targeting of homologous DNA recombination repair by gemcitabine. Int J Radiat Oncol Biol Phys 57: 553-625

12. Robinson BW, Shewach DS (2001) Radiosensitization by gemcitabine in p53 wildtype and mutant MCF-7 breast carcinoma cell lines. Clin Cancer Res 7: 2581-2589

13. Robinson BW, Im MM, Ljungman M, Praz F, Shewach DS (2003) Enhanced radiosensitization with gemcitabine in mismatch repair-deficient HCT116 cells. Cancer Res 63: 6935-6941

14. Cranea CH, Varadhachary G, Settlea SH, Fleming JB, Evans DB, Wolff RA (2009) The integration of chemoradiation in the care of patient with localized pancreatic cancer. Cancer Radiother 13: 123-143

15. Evans DB, Varadhachary GR, Crane CH, Sun CC, Lee JE, Pisters PW, Vauthey JN, Wang $\mathrm{H}$, Cleary KR, Staerkel GA, Charnsangavej C, Lano EA, Ho L, Lenzi R, Abbruzzese JL, Wolff RA (2008) Preoperative gemcitabine-based chemoradiation for patients with resectable adenocarcinoma of the pancreatic head. J Clin Oncol 26: $3496-3502$ 
16. Rose PG, Degeest K, McMeekin S, Fusco N (2007) A phase I study of gemcitabine followed by cisplatin concurrent with whole pelvic radiation therapy in locally advanced cervical cancer: a Gynecologic Oncology Group study. Gynecol Oncol 107: $274-279$

17. Dueñas-González A, Zarba JJ, Alcedo JC, Pattarunataporn P, Beslija S, Patel F, Casanova L, Barraclough H, Orlando M (2009) A phase III study comparing concurrent gemcitabine (Gem) plus cisplatin (Cis) and radiation followed by adjuvant Gem plus Cis versus concurrent $\mathrm{Cis}$ and radiation in patients with stage IIB to IVA carcinoma of the cervix. J Clin Oncol 27: 18s, (suppl; abstr CRA5507)

18. Eisbruch A, Shewach DS, Bradford CR, Littles JF, Teknos TN, Chepeha DB, Marentette LJ, Terrell JE, Hogikyan ND, Dawson LA, Urba S, Wolf GT, Lawrence TS (2001) Radiation concurrent with gemcitabine for locally advanced head and neck cancer: a phase I trial and intracellular drug incorporation study. J Clin Oncol 19: 792-799

19. Specenier PM, Van den Weyngaert D, Van Laer C, Weyler J, Van den Brande J, Huizing MT, Dyck J, Schrijvers D, Vermorken JB (2007) Phase II feasibility study of concurrent radiotherapy and gemcitabine in chemonaive patients with squamous cell carcinoma of the head and neck: long-term follow up data. Ann Oncol 18: 1856-1860

20. Specenier PM, Weyler J, Van Laer C, Van den Weyngaert D, Van den Brande J, Huizing MT, Altintas S, Vermorken JB (2009) A non-randomized comparison of gemcitabine-based chemoradiation with or without induction chemotherapy for locally advanced squamous cell carcinoma of the head and neck. BMC Cancer 9: 273 
21. Abbruzzese JL, Grunewald R, Weeks EA, Gravel D, Adams T, Nowak B, Mineishi S, Tarassoff P, Satterlee W, Raber MN (1991) A Phase I Clinical, Plasma, and Cellular Pharmacology Study of Gemcitabine. J Clin Oncol 9: 491-498

22. Peters GJ, Clavel M, Noordhuis P, Geyssen GJ, Laan AC, Guastalla J, Edzes HT, Vermorken JB (2007) Clinical phase I and pharmacology study of gemcitabine (2', 2'-difluorodeoxycytidine) administered in a two-weekly schedule. J Chemother 19: 212-221.

23. Pauwels B, Korst AEC, Lambrechts AEJ, Pattyn GGO, de Pooter CMJ, Lardon F, Vermorken JB (2006) The radiosensitising effect of difluorodeoxyuridine, a metabolite of gemcitabine, in vitro. Cancer Chemother Pharmacol 58: 219-228.

24. http://www.rtog.org/members/toxicity/acute.html accessed on January 28, 2010

25. Mini E, Nobili S, Caciagli B, Landini I, Mazzei T (2006) Cellular pharmacology of gemcitabine. Ann Oncol 17 (Suppl 5): v7-v12

26. Wong A, Soo RA, Yong WP, Innocenti F (2009) Clinical pharmacology and pharmacogenetics of gemcitabine. Drug Metab Rev 41: 77-88

27. Danesi R, Altavilla G, Giovannetti E, Rosell R (2009) Pharmacogenomics of gemcitabine in non-small-cell lung cancer and other solid tumors. Pharmacogenomics 10: 69-80

28. Ueno H, Kiyosawa K, Kaniwa N (2007) Pharmacogenomics of gemcitabine: can genetic studies lead to tailor-made therapy? $\mathrm{Br}$ J Cancer 97: 145-151 
29. Kim SR, Saito Y, Maekawa K, Sugiyama E, Kaniwa N, Ueno H, Okusaka T, Ikeda M, Morizane C, Yamamoto N, Yoshida T, Kamatani N, Furuse J, Ishii H, Saijo N, Ozawa S, Sawada J (2008) Twenty novel genetic variations and haplotype structures of the DCK gene encoding human deoxycytidine kinase (dCK). Drug Metab Pharmacokinet 23: 379-384

30. Giovannetti E, Laan AC, Vasile E, Tibaldi C, Nannizzi S, Ricciardi S, Falcone A, Danesi R, Peters GJ (2008) Correlation between cytidine deaminase genotype and gemcitabine deamination in blood samples. Nucleosides Nucleotides Nucleic Acids 27: $720-725$

31. Sugiyama E, Kaniwa N, Kim S-R, Kikura-Hanajiri R, Hasegawa R, Maekawa K, Saito Y, Ozawa S, Sawada J-I, Kamatani N, Furuse J, Ishii H. Yoshida T, Ueno H, Okusaka T, Saijo N (2007) Pharmacokinetics of Gemcitabine in Japanese Cancer Patients: The Impact of a Cytidine Deaminase Polymorphism. J Clin Oncol 25: 3242

32. http://pi.lilly.com/us/gemzar.pdf accessed on January 28, 2010.

33. Koolen SL, Huitema AD, Jansen RS, van Voorthuizen T, Beijnen JH, Smit WM, Schellens JH (2009) Pharmacokinetics of gemcitabine and metabolites in a patient with double-sided nephrectomy: a case report and review of the literature. Oncologist 14: $944-948$

34. Kiani A, Köhne CH, Franz T, Passauer J, Haufe T, Gross P, Ehninger G, Schleyer E (2003) Pharmacokinetics of gemcitabine in a patient with end-stage renal disease: effective clearance of its main metabolite by standard hemodialysis treatment. Cancer Chemother Pharmacol 51: 266-270 
Table 1: Patient, tumor and treatment characteristics

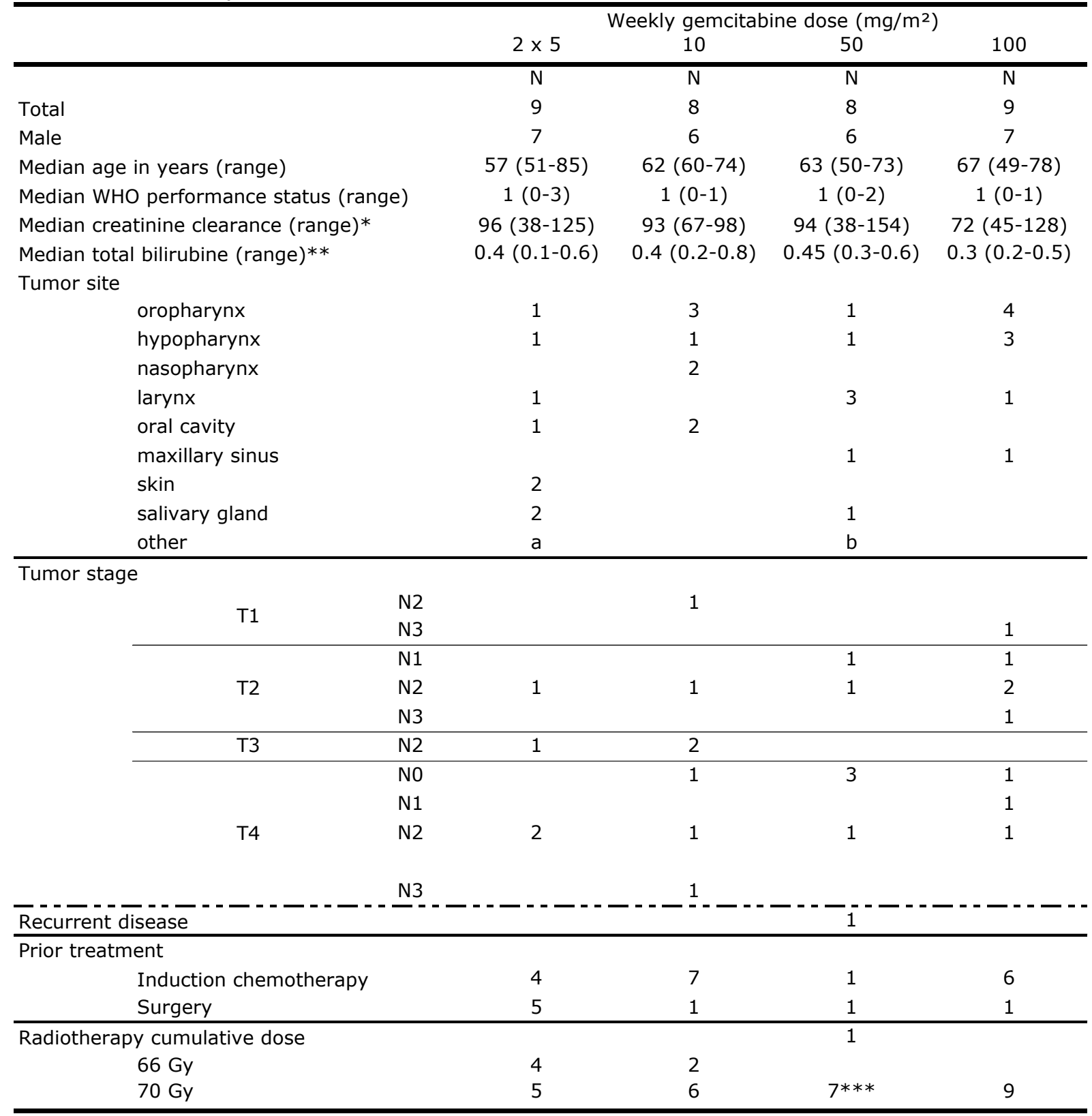

a: unknown primary; b: tumor of vestibulum nasi; *: $\mathrm{ml} / \mathrm{min}$, calculated using the Modified Cockcroft-Gault formula; **: $\mathrm{mg} / \mathrm{dl}$; ***: radiotherapy was stopped after $42 \mathrm{~Gy}$ in 1 patient due to toxicity 
Table 2: First-week dFdU AUC and dFdU trough concentrations

\begin{tabular}{lcccc}
\hline & \multicolumn{3}{c}{ weekly gemcitabine dose $\left(\mathrm{mg} / \mathrm{m}^{2}\right)$} \\
& $2 \times 5$ & 10 & 50 & 100 \\
\hline Median AUC (ng.hour/ml) & 46371 & 48840 & 161884 & 205908 \\
Trough conc. $(\mathrm{ng} / \mathrm{ml})$, median of mean* & 418 & 248 & 613 & 527 \\
Trough conc. $(\mathrm{ng} / \mathrm{ml})$, range of mean & $118-559$ & $25-2987$ & $384-2201$ & $211-1118$ \\
\hline
\end{tabular}

*for each patient; AUC = area under the concentration-curve

Table 3: Relevant correlations

\begin{tabular}{llcc}
\hline Independent variable & Dependent variable & $\mathrm{r}$ & $\mathrm{p}$ \\
\hline gemcitabine dose $\left(\mathrm{mg} / \mathrm{m}^{2}\right)$ & mean trough concentration & .339 & .05 \\
gemcitabine dose $\left(\mathrm{mg} / \mathrm{m}^{2}\right)$ & AUC & .805 & $<.0001$ \\
gemcitabine dose $\left(\mathrm{mg} / \mathrm{m}^{2}\right)$ & weeks grade 3/4 mucositis & .535 & .001 \\
total gemcitabine dose & AUC & .803 & $<.0001$ \\
total gemcitabine dose & mean trough concentration & .408 & 0.017 \\
total gemcitabine dose & weeks grade 3/4 mucositis & .592 & $<.0001$ \\
total dose divided by creatinine clearance & mean trough concentration & .364 & .034 \\
total dose divided by creatinine clearance & AUC & .818 & $<.0001$ \\
creatinine clearance & AUC & -.305 & .073 \\
\hline
\end{tabular}

$r=$ Spearman's rho correlation factor; $A U C=$ area under the concentration-curve 
Table 4: Non-hematologic toxicities

Patients who received no induction chemotherapy

gemcitabine dose $\left(\mathrm{mg} / \mathrm{m}^{2}\right)$ : $\mathrm{N}$ : Pharyngitis

Dermatitis

Mucositis

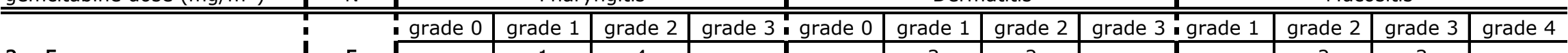

$2 \times 5$

10

50

5

100

\begin{tabular}{|c|c|r} 
grade 0 & grade 1 & grade \\
\hline & 1 & 4
\end{tabular}

| 1

1

Patients who received induction chemotherapy

gemcitabine dose $\left(\mathrm{mg} / \mathrm{m}^{2}\right)$ : $\mathrm{N}$

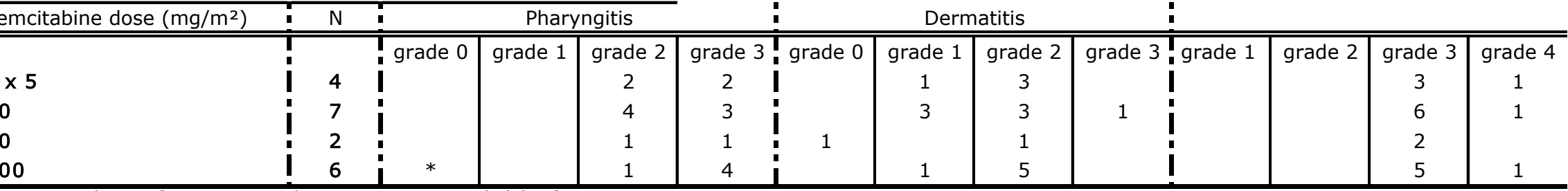

$2 \times 5$

10

50

100

$\mathrm{N}=$ number of patients; $*$ : no score available for 1 patient

\begin{tabular}{|c|c|c|c|c|c|c} 
grade 1 & grade 2 & grade 3 & grade 1 & grade 2 & grade 3 & grade 4 \\
\hline 3 & 2 & & & 2 & 3 & \\
1 & & & & & 1 & \\
1 & 3 & 1 & & & 6 & \\
& 2 & 1 & & & 3 & \\
\hline
\end{tabular}




\section{Table 5: Hematologic Toxicities}

\begin{tabular}{|c|c|c|c|c|c|c|c|c|c|c|c|c|c|}
\hline \multicolumn{14}{|c|}{ Patients who received no induction chemotherapy } \\
\hline & & grade 0 & grade 1 & grade 2 & grade 3 & grade 0 & grade 1 & grade 2 & grade 0 & grade 1 & grade 2 & grade 3 & grade 4 \\
\hline $2 \times 5$ & 5 & 3 & 1 & 1 & & 3 & 2 & & 5 & & & & \\
\hline 50 & 6 & 3 & 3 & & 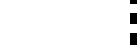 & 3 & 3 & & 3 & 2 & 1 & & \\
\hline 100 & 3 & & 2 & 1 & & 3 & & & 2 & 1 & & & \\
\hline \multicolumn{14}{|c|}{ Patients who received induction chemotherapy } \\
\hline gemcitabine dose $\left(\mathrm{mg} / \mathrm{m}^{2}\right)$ & $\mathrm{N}$ & & \multicolumn{2}{|c|}{ Hemoglobin } & \multicolumn{4}{|c|}{ Thrombocytes } & \multicolumn{5}{|c|}{ ANC } \\
\hline & & grade 0 & grade 1 & grade 2 & grade 3 & grade 0 & grade 1 & grade 2 & grade 0 & grade 1 & grade 2 & grade 3 & grade 4 \\
\hline $2 \times 5$ & 4 & & 2 & 2 & & 2 & 2 & & 4 & & & & \\
\hline 10 & 7 & & 3 & 3 & 1 & 5 & 2 & & 7 & & & & \\
\hline 50 & 2 & & 1 & 1 & & 1 & 1 & & 1 & 1 & & & \\
\hline 100 & 6 & & & 5 & 1 & 2 & 3 & 1 & 2 & 2 & 1 & & 1 \\
\hline
\end{tabular}

$\mathrm{N}=$ number of patients; $\mathrm{ANC}=$ absolute neutrophil count 
Figure legends

Figure 1: First-week dFdU area under the concentration-time curve (AUC) versus gemcitabine dose 
Figure 2: dFdU concentrations (median and range) in the first 7 days in the four different gemcitabine dose groups

$* 0:$ Symbols and numbers represent outliers 
Figure 3: Mean of all dFdU trough concentrations (and 95\% confidence intervals) in the four gemcitabine dose groups 
Figure 4: Weeks with grade 3 or 4 mucositis versus gemcitabine dose

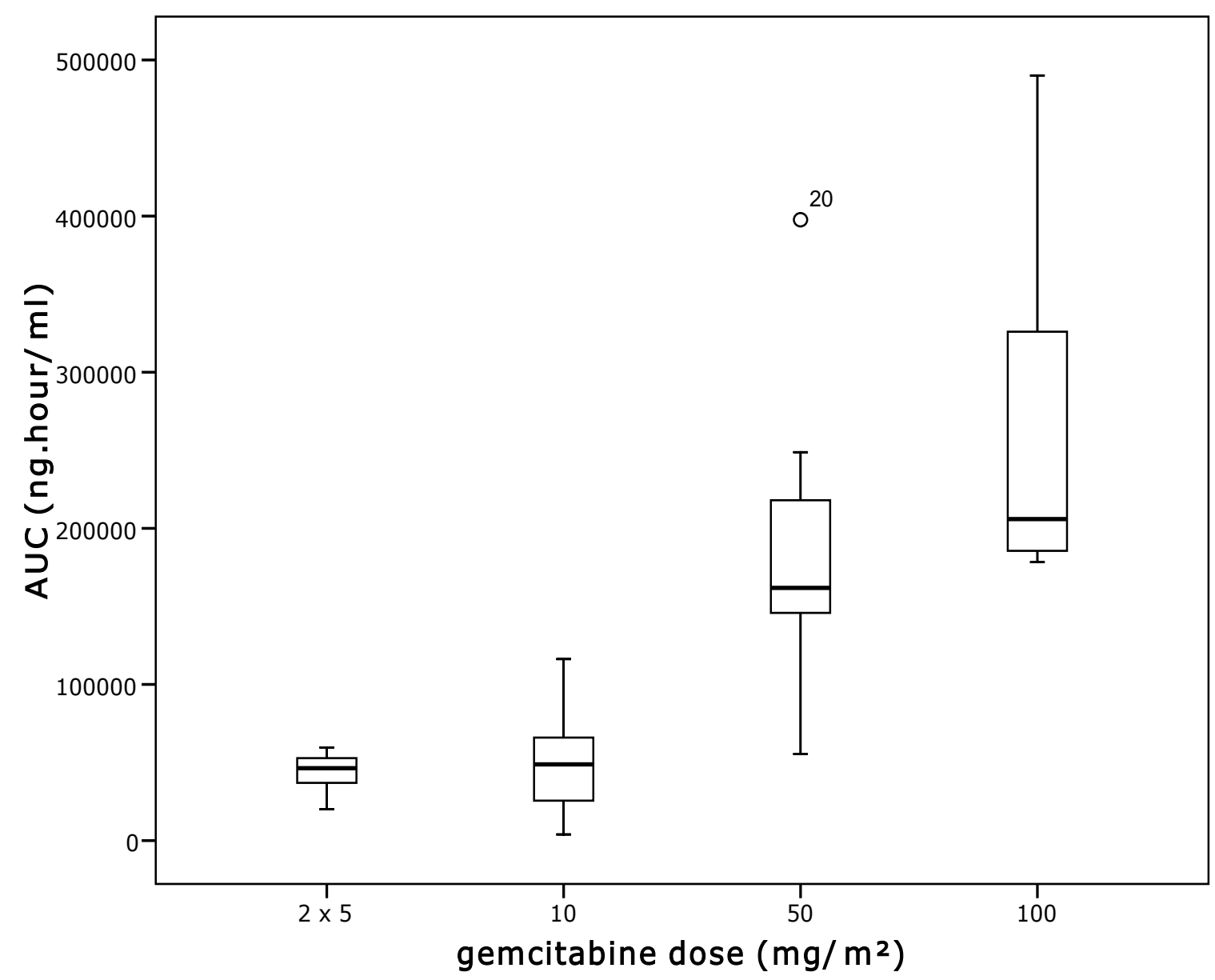




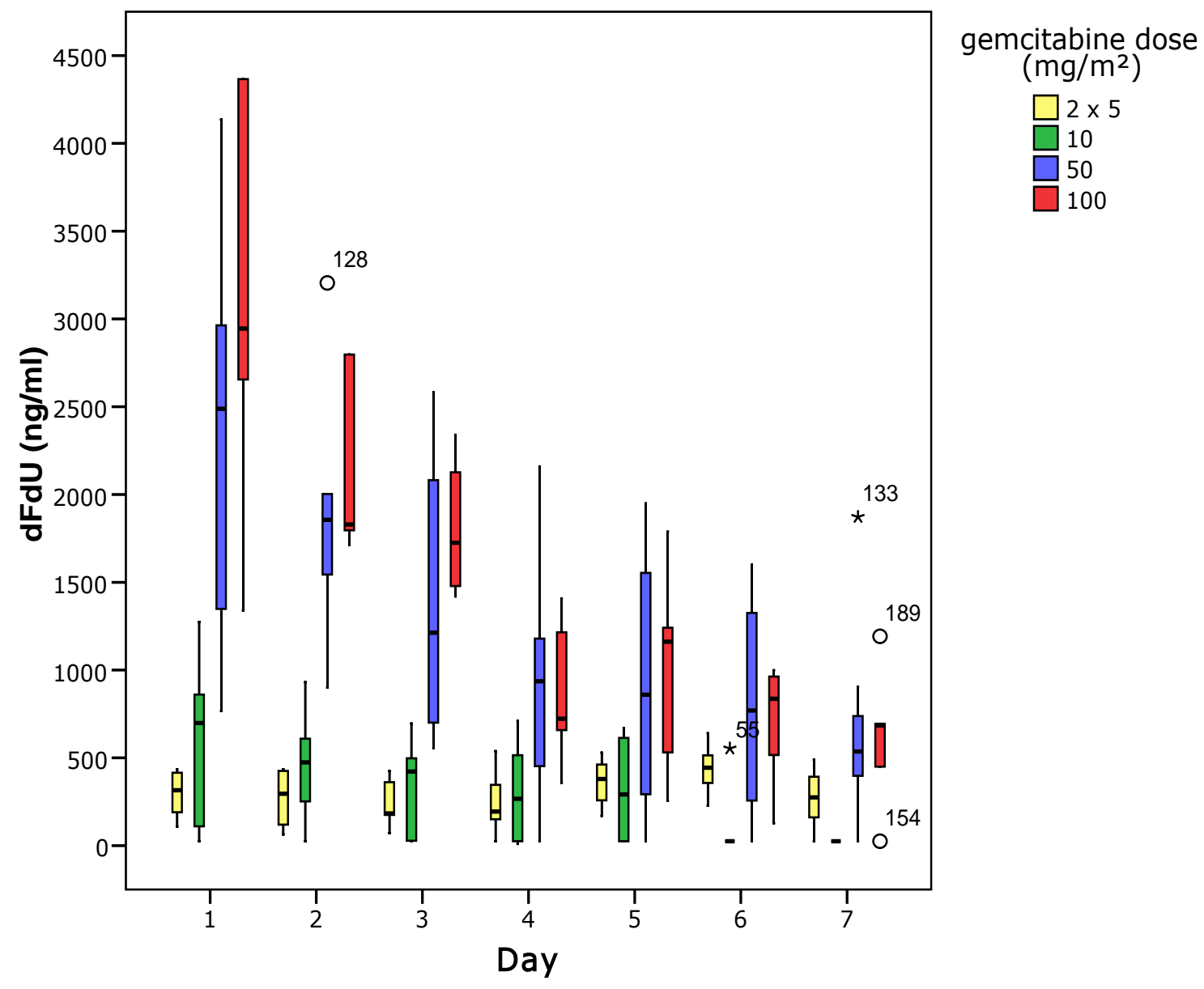




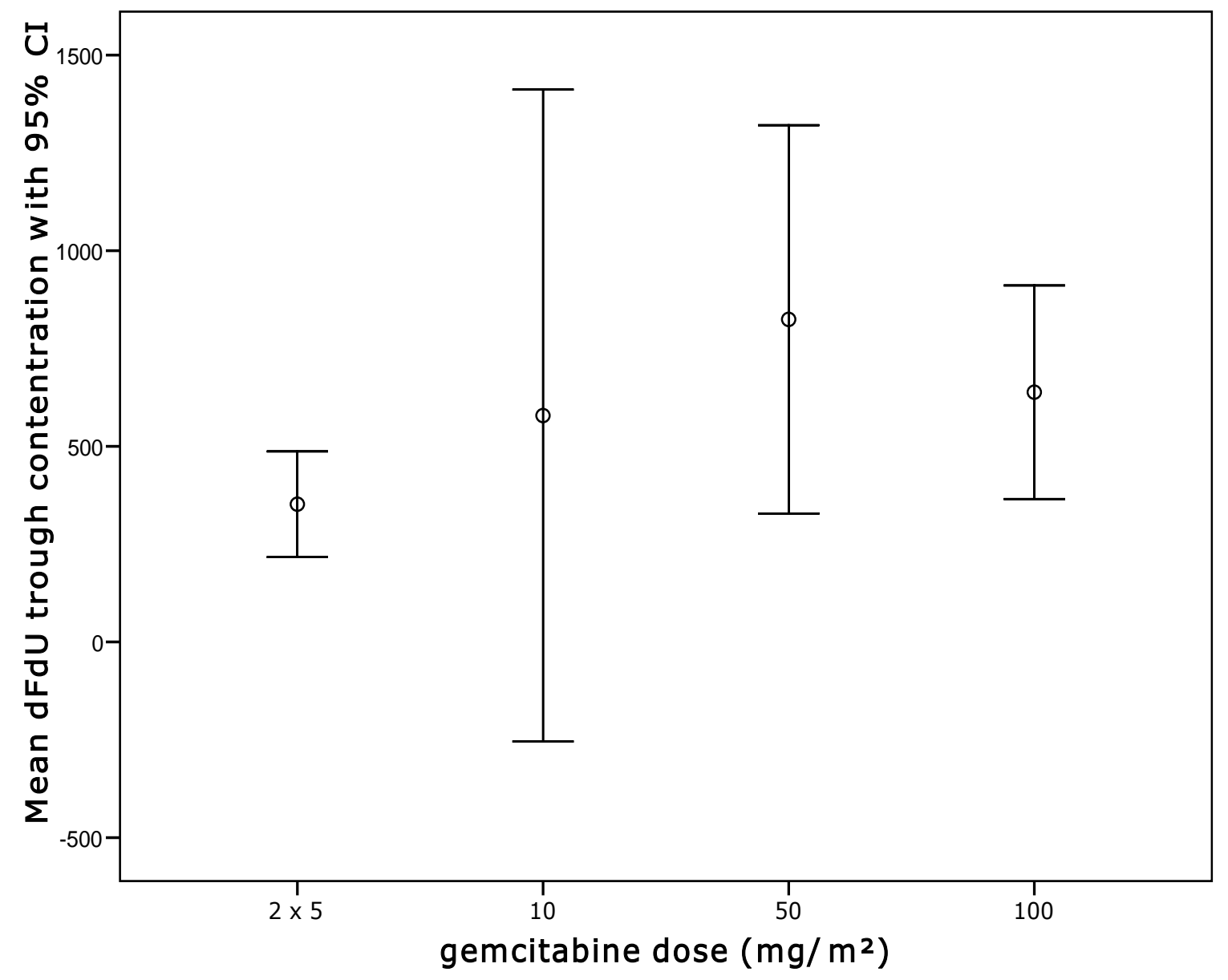




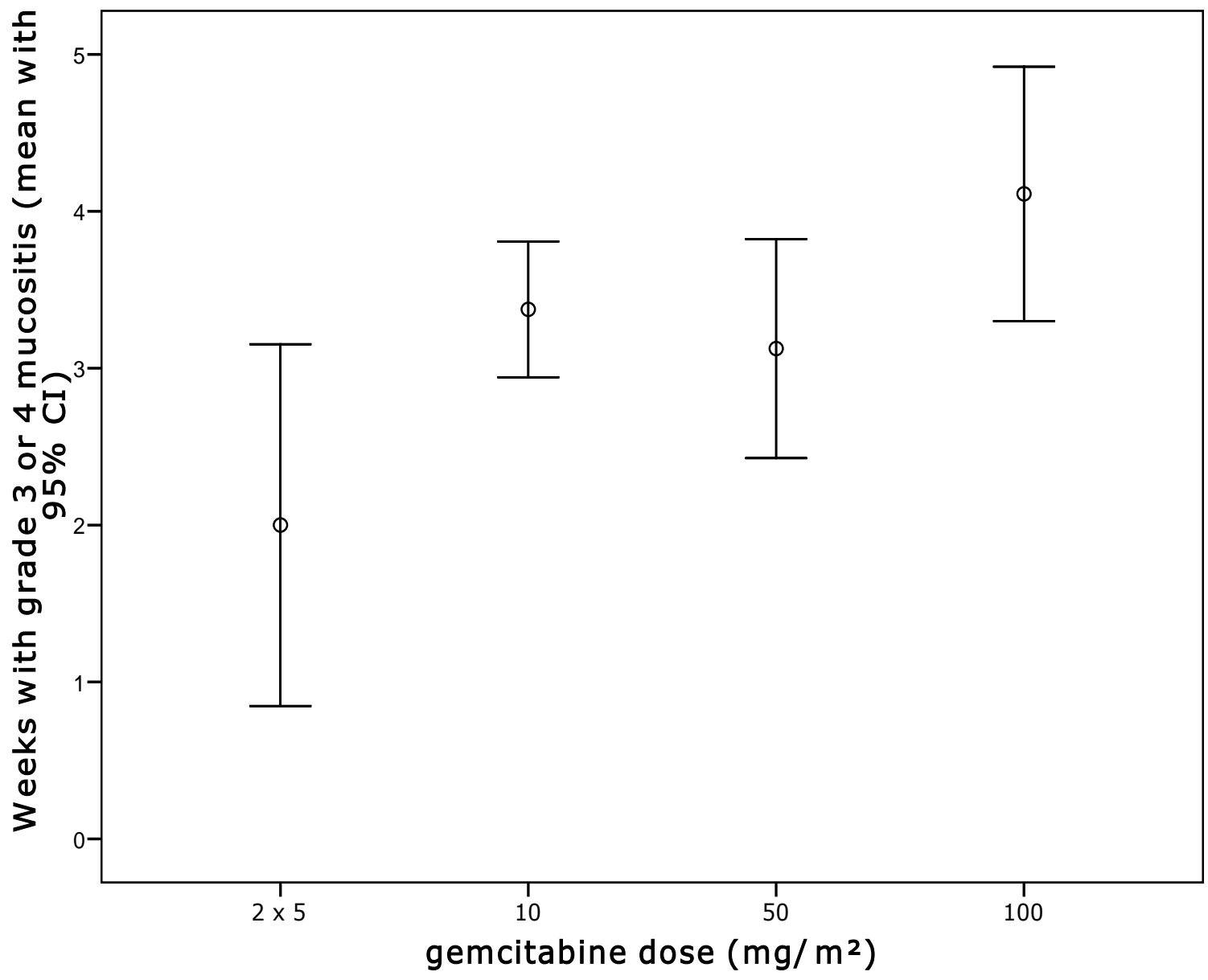

